\title{
Final Technical Report
}

\author{
Swift Wind Turbine Testing \\ DE-EE0000547
}

Project Period: December 2009 - April 2013

Richard Peek

(616) 975-4872

Rich.peek@cascadeng.com

Cascade Engineering

3400 Innovation Ct SE

Grand Rapids, MI 49512

July 22, 2013 
Acknowledgment: This report is based upon work supported by the U. S. Department of Energy under Award No. DE-EE0000547.

Disclaimer: Any findings, opinions, and conclusions or recommendations expressed in this report are those of the author(s) and do not necessarily reflect the views of the Department of Energy. 


\section{Table of Contents}

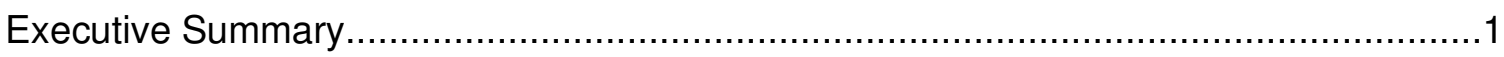

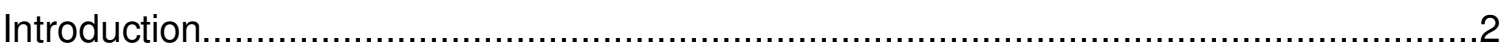

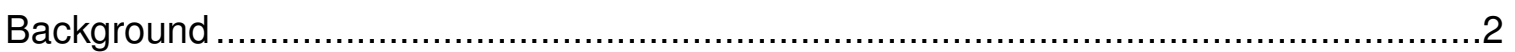

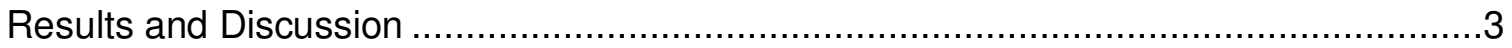

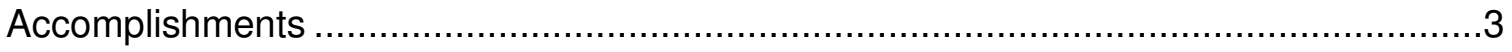

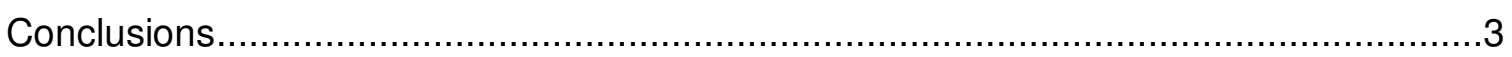

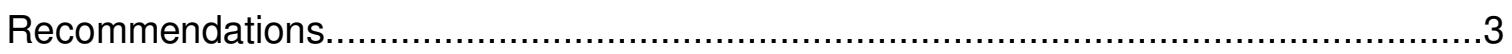

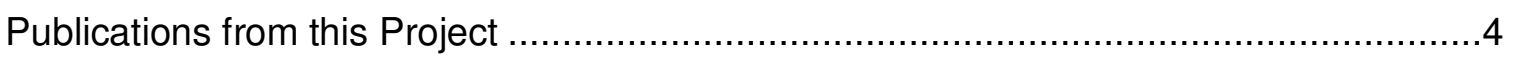




\section{Executive Summary}

The purpose of this project was to independently test the Swift wind turbine according to the AWEA Small Wind Turbine Performance and Safety Standard. This project was part of the U.S. Department of Energy's (DOE's) Independent Testing project. The project was established to help providers of small wind turbines the opportunity to validate the product to AWEA standards. The National Wind Technology Center (NWTC) conducted testing that included duration, safety and function, power performance, and acoustic.

Successful operation of the turbine was confirmed in the results of the testing. Duration requirements were met, there were no safety issues, power performance was established, and the acoustic level was verified to be low compared to other similar turbines. Data results can be assembled and submitted to the Small Wind Certification Council (SWCC) for certification of the turbine to AWEA standards. 


\section{Introduction}

The Swift wind turbine is a small, building mountable turbine with a rotor size of $7 \mathrm{ft}$. Patented features include the diffuser ring that connects the five blades at the tips. This diffuser ring reduces vibration and noise. The reduction of vibration and noise affords the turbine to be building mounted when properly done according to the installation instructions. The building mounting feature allows more consumers to have the option to wind energy, as many communities have restrictions with regard to turbines mounted on poles.

Prior to the establishment of an AWEA small wind turbine standard, and the eventual creation of the Small Wind Certification Council (SWCC), manufacturers tested and rated their turbines differently. Third party, certified, testing was expensive and in most cases, beyond the financial reaches of the small wind turbine manufacturers. Manufacturers did not have the money to pay a third party to test their turbine. This grant provided the financial means to properly test the Swift wind turbine according to the AWEA small wind turbine performance and safety standard.

\section{Background}

The objective of this project was to test the Swift turbine to the following standards:

- Power Performance Measurements of Electricity Producing Wind Turbines, IEC 61400-12-1 Ed.1.0, 2005-12. Because the SWIFT is a small turbine according to the IEC definition, NREL also followed Annex $\mathrm{H}$

- Safety and Function Test - Wind Turbines-Part 2: Design Requirements for Small Wind Turbines," IEC61400-2, second edition, 2006-03; Section 9.6

- Duration Test - Wind Turbines-Part 2: Design Requirements for Small Wind Turbines," IEC61400-2, second edition, 2006-03; Clause 9.4

- Wind Turbine Generator Systems - Part 11: Acoustic Noise Measurement Techniques, IEC 61400-11, Edition 2.1, 2006-11

All testing was performed at the NWTC, a wind turbine testing site located in Boulder, Colorado. NWTC is part of NREL. NREL is an accredited laboratory through the American Association for Laboratory Accreditation (A2LA). 


\section{Results and Discussion}

Formal technical reports were completed for each section of the small wind turbine testing by NWTC personnel. Results for the individual reports can be found with the following links:

- Duration:

http://www.nrel.gov/docs/fy13osti/57126.pdf

- Safety and Function: $\quad$ http://www.nrel.gov/docs/fy13osti/57125.pdf

- Power Performance: $\quad$ http://www.nrel.gov/docs/fy13osti/56499.pdf

- Acoustic:

http://www.nrel.gov/docs/fy13osti/58244.pdf

The turbine achieved reliable operation (according to the standard) over the 20 months that it was installed. It met the duration requirements after approximately 13 months.

The turbine exhibited no unexpected or inherently unsafe behavior during the investigation of safety and function.

Power performance testing found the turbine to produce 900 watts at $11 \mathrm{~m} / \mathrm{s}$ when normalized to air density at sea level $\left(1.225 \mathrm{~kg} / \mathrm{m}^{\wedge} 3\right)$. In an annualized energy rating, the turbine would produce $734 \mathrm{kwh}$ at an average speed of $5.0 \mathrm{~m} / \mathrm{s}$.

In the acoustic testing, the turbine was determined to be $38.3 \mathrm{dBa}$ as measured by the AWEA rated sound level.

\section{Accomplishments}

All testing as required by AMEA small wind turbine standard were completed. The data is ready to be submitted to the SWCC for certification of the turbine.

No patent applications were submitted during the time of this testing.

\section{Conclusions}

The Swift wind turbine met the duration requirements, functioned safely, verified energy production, and was found to be one of the quietest turbines on the market. This third party verification can be used to further promote the sale of the turbine in the market.

\section{Recommendations}

If it is determined that certification will increase market demand for the product, an application can be pursued with the SWCC to obtain turbine certification. 


\section{Publications from this Project}

I. Mendoza, I .Hur, J. (2013). Duration Test Report for the SWIFT Wind Turbine. National Renewable Energy Laboratory

I. Mendoza, I .Hur, J. (2013). Safety and Function Test Report for the SWIFT Wind Turbine. National Renewable Energy Laboratory

I. Mendoza, I .Hur, J. (2013). Power Performance Test Report for the SWIFT Wind Turbine. National Renewable Energy Laboratory

Roadman, J.; Huskey, A. (2013). Acoustic Noise Test Report for the SWIFT Wind Turbine in Boulder, CO. National Renewable Energy Laboratory 